\title{
A politikai filozófia a világjárványról
}

\author{
Hörcher Ferenc \\ Nemzeti Közszolgálati Egyetem, Eötvös József Kutatóközpont, Politika- és Államelméleti Kutatóintézet, \\ Budapest, Magyarország \\ Bölcsészettudományi Kutatóközpont Filozófiai Intézet, Budapest, Magyarország
}

Beérkezett: 2021. július 19.; Elfogadva: 2021. szeptember 13.

\section{Összefoglalás}

Ez a filozófiai esszé arra tesz kísérletet, hogy megpróbálja nyomon követni a világjárvány kibontakozását, a változatos védelmi stratégiákat, valamint a mégiscsak bekövetkező tragédiákat a politikai filozófia perspektívájából. Mégpedig valós időben. Az esszé abból a hipotézisből indul ki, hogy az emberiséget váratlanul érte ugyan a járvány, mégis igen gyorsan tudott reagálni (lásd az oltóanyag előállításának gyorsaságát), az egyes emberek azonban nem tudtak kilépni saját természetük korlátai közül. Ennek megfelelően a hatalom ismét elkövette a szokásos hibákat, a lázadók lázadtak, és a politika továbbra is a konfliktusok kezelésének múvészete maradt. A politikával foglalkozóknak azonban kincsesbánya ez a korszak a politika természetének elemzéséhez.

Kulcsszavak: pandémia, hatalom, nemzetközi kapcsolatok, bizalmatlanság, az együttmúködés hiánya

\section{The Pandemic, from the Perspective of Political Philosophy}

\author{
Ferenc Hörcher \\ University of Public Service, Eötvös József Research Centre, Research Institute for Politics and Government, \\ Budapest, Hungary \\ Research Centre for the Humanities, Institute of Philosophy, Budapest, Hungary
}

\begin{abstract}
Summary
This paper, written in the genre of the literary essay, tries to keep track of the birth and development of the pandemic, the various defence strategies and the tragedies that took place anyhow, from the perspective of the discipline of political philosophy.

Now political philosophy is not characteristically ready to react promptly to the events of the day. It has got a long term perspective, and therefore has no intention to keep an eye on the headlines of the online news portals. It has got long term debits, which cannot be easily paid back in cash.

And yet the claim of the paper is that in fact we are confronted by a state of affairs when political philosophy is obliged to take note of contemporary events. And it has to try to respond to those events almost "real time" or directly. We are aware of 4 million dead, by now, which is an unacceptable number.

To tackle states of emergency parliaments are usually ready to offer exceptional measures for government action, even in parliamentary democracies. Yet politicians do not necessarily want to take on board the struggle with the virus - they can easily drop it out from the issues of the day -, claiming that public health should not be politicized. Yet by leaving the stage to let professional experts make the decisions, they give up their chance to unite the camp. Statesmen can only unite their camp behind them, if they make use of the window of opportunity opened by an emergency situation, and if they are able to make use of the phobias and anxieties of everyday people, in the fashionable populist, plebeian manner.

The essay analyses two basic relationships influenced by the pandemic. One is claimed to be the intergovernmental, or global scene. Here, the great and developing powers are competing with each other, through the still mostly acceptable international norms of taking advantage of inequality. The other is the inner political scene, where there is a growing distrust between the authorities and the ordinary people, fuelled by restrictions, fake news, and forms either of controlling society by illegal means, or of influencing leaders by indirect means.

The last part of the essay presents three major aspects from where one can analyse the happenings: a social, a communicational and an economic perspective on its effects.

The essay finishes with some cautionary, sceptical notes on human nature, in order to keep vigilance in emergency situations on the loss of balance, either internal or external, to avoid the major dangers.
\end{abstract}

Keywords: pandemic, source of power, international relations, lack of trust, no cooperation 


\section{Bevezetés}

Hasonló súlyú, azonnali kihívással a ma élő emberiség még nem találkozott. Mintegy 200 millió fertőzött, 4 millió halott. És akkor még a gazdasági, politikai és társadalmi hatásokról nem is esett szó. Csak a klímaválsághoz hasonlítható az a kihívás, amit a koronavírus világjárvány jelent, minden egyes emberi közösség számára külön-külön, s az emberiség egésze számára is.

A vészhelyzet cselekvést igényel, azt gondolnánk, a reflexió majd utána következik. Ám nincs megfelelő cselekvés megfelelő gondolat nélkül. Ebből a küzdelemből a társadalomtudománynak, s azon belül a filozófiának is ki kell vennie a részét. Valós idejü gondolati munkára van szükség: a pillanatra reagáló, de a lényeges elemeket feltárni igyekvő gondolkodásra.

Az alább olvasható feljegyzések még nem igazán formalizált gondolatok, inkább ötletek, gondolatcsírák. Sajátosságuk, hogy az általuk elemzett jelenségekkel egy időben születtek. Céljuk nem valamifajta általános érvényü igazság megtalálása, inkább az, hogy a váratlanul kialakult vészhelyzet további elemzéséhez muníciót szolgáltassanak. A vészhelyzetre azzal egyidejúleg adott (nem válasz, csak) reakció ugyanis nemcsak fontos kapaszkodó a vészhelyzettel való szembesülés során, hanem egyben lenyomata is a bemutatott jelenségnek. Enynyiben a késóbbi alaposabb értelmezés számára is forrásként szolgálhat majd. ${ }^{1}$

\section{Valós idejü üzemmód}

A filozófia általában utólag okos. ${ }^{2}$ A politikával kapcsolatos filozófiai vizsgálódás szokásos módja szerint ugyanis hozott anyagból dolgozik. A múlt hírnökei, a történetírók szolgáltatják a legfontosabb muníciót azoknak, akik a politikáról elméleti igénnyel szeretnének valamit mondani. Szemben a természettudományos vizsgálódással, a politika vizsgálatára vállalkozónak általában nincs lehetősége arra, hogy saját szemével győződhessen meg az általa felállított hipotézis igazságáról, hogy kísérleti úton járjon utána annak, ami érdekli. Vagyis nem tud mindent a saját tapasztalata alapján megírni, mások tapasztalatait is be kell vonnia, s elmúlt korok beszámolóit is rendre mozgósítania kell. David Hume volt az, aki a politikával kapcsolatos elméleti-tudományos vizsgálódásokat épp ezért tekintette kezdeti szakaszban lévőnek, mert nem áll a kutató rendelkezésére megfelelő mennyiségü, saját

\footnotetext{
A modern európai történelemnek számos olyan korszaka volt, amikor a kialakult politikai helyzet gyümölcsöző elméleti irodalmat eredményezett. Ide számíthatjuk a reformáció utáni korszakot, amikor Bodintől Hobbes-ig egy új államfogalom született (Skinner 2009: 325); a francia forradalmat követó időszakot, amikor a mai politikai ideológiák megszülettek (Freeden 1996); s a huszadik század közepét, amikor a totalitárius ideológiákkal való szembenézésnek kellett megtörténnie, Hayektől és Koestlertől Orwellig és Arendtig (BallBellamy 2003)

${ }^{2}$ Lásd erről Hegel sokszor emlegetett mondását: „Minerva baglya csak a beálló alkonnyal kezdi meg röptét.” (Hegel 1971: 23).
}

maga által tesztelt adat (Hume 1992: I. 27-42). A politikát nem tudjuk a természettudományhoz hasonló módszertannal tanulmányozni. Az ok-okozati összefüggéseket nehezen tudjuk tesztelni - már csak az emberi életre jellemző időbeli, tudásbeli és helyzetbeli korlátokból kifolyólag is. Ha sem a tesztelésnek, sem az obszervációnak nincs elég alapanyaga, akkor bizony szükség van a múltból származó információ bevonására is, hogy minél nagyobb mennyiségú megfigyelésre támaszkodhassunk.

Ám nyilvánvaló, hogy a politikában a megfigyelő személye, az adatgyújtés, illetve az adatrögzítés módja befolyásolni fogja az adatok minőségét. Mindez azt eredményezi, hogy a „tudományosság” így is sokkal korlátozottabb marad, mint a politikatudományban. S még sokkal inkább igaz ez a megállapítás a politikai filozófiára, mely egyetemes érvényű belátásokra szeretne jutni, egy radikális ütemben és folyamatosan változó világban. Ezért aztán a politikai filozófus nemcsak a történet- és emlékiratírókkal folytat eszmecserét, hanem a filozófiai kánon szerzőivel is beszélget, megpróbálja az általuk öszszegyújtött tanulságokat is hasznosítani a saját vizsgálódásai során.

Nem könnyű tehát a politikai filozófus dolga. Hiszen a politikától nincs sok dolog távolabb, mint épp a filozófia. S mivel a politika nem modellezhető, bölcselőnk nagyon nehezen juthat megbízható vizsgálati adathoz, amelyet ne torzítana a történelmi távolság vagy a nézőpontok közötti eltérés.

Azt állítom azonban, hogy a világjárvány páratlan lehetőséget kínál a politikai filozófus számára is a tapasztalatszerzésre, a megfigyelésre, és az azonos kihívásokra - persze közel sem azonos körülmények között - adott eltérő válaszok összehasonlító vizsgálatára. Tulajdonképpen valós idejü vizsgálódásra kell vállalkoznia, a folyamatokat látva, azokat azonnal elemeznie kell. Ezzel együtt saját gondolkodási keretrendszere is szükségszerűen át fog alakulni a tapasztalati horizont tágulásával. Folyamatos finomhangolásra lesz szüksége, beleértve a filozófiai módszertan kérdéseit is. Azt is figyelembe kell azonban venni, hogy a megfigyelő és a megfigyelt dolog közötti távolság a valós idejű filozófiai analízissel minimálisra csökken, s ennek megfelelően elemzőnk adott esetben a fától nem fogja látni az erdőt. Ha például rajta is erőt vesz a szorongás, az nyilván ki fog hatni nemcsak az adatgyưjtésre, de az azzal együtt futó adatfeldolgozásra is. A félelem ugyanis csakugyan nem jó tanácsadó, márpedig a világjárvány az egyes ember számára szinte elkerülhetetlenül félelmetes jelenségegyüttesnek tünik - már csak a halottak számából kifolyólag is. A filozófus megfigyeléseinek ezért részben épp magára kell irányulnia - ebben a helyzetben a politikának kitett én válhat a politikára reflektáló én megfigyelésének tárgyává.

De azért nem kell nagyon megijednie: különös módon adott esetben épp ez az önreflexiós tevékenység lehet a legjobb orvossága magának a szorongásnak. A filozófia egyik legfontosabb feladata ugyanis, s egyben az emberi méltóság alapja, ahogy erre Kant is felhívta a figyelmet, 
az, hogy ha az ember megváltoztatni nem is feltétlenül tudja, érthetőbbé tegye az ôt körülvevő világot (Balázs 2005). Épp ez a lehetôség adja az ember méltóságát szerinte: hogy még ha meg nem is tudja változtatni az események folyását, meg tudja érteni, vagyis értelmével uralni tudja azokat. Ennyiben a vészhelyzetben folytatott valós idejű filozófiai vizsgálódás terápiaként és önterápiaként is szolgálhat: az értelem segítségül hívása révén esetleg orvosolhatja a megfigyelő szorongását is.

\section{Politika vészhelyzetben}

A politikai legitimáció megerősítésének legrégebben ismert eszközei közé tartozik a vészhelyzet meghirdetése. A vészhelyzetben ugyanis a tábor felcsatlakozik vezetójéhez. Gondoljunk Lady Thatcher brit miniszterelnök falklandi háborújára, 1982-bőll. A brit miniszterelnöknek kapóra jött a háború népszerúsége visszaszerzésére. Politikai értelemben a pandémia épp azt a vészhelyzetet jelenti, amely kulcsfontosságúnak nevezhetó a politika világában. Olyan kihívás a politikai közösség egészével szemben, amely miatt a többség hajlamos felcsatlakozni a mindenkori vezető mögé.

A vészhelyzet legelemibb formája a háború. Ha az ellenség rátör a hazára, veszélyeztetve a polgárok életét, felforgatva annak intézményrendszerét és lerombolva infrastruktúráját is, a polgár nem kérdez, hanem védőnek áll, hogy biztosítsa a közösség túlélését a támadóval szemben. Vészhelyzet idején az erőket összpontosítani szokták, ilyenkor mindenkitől áldozatot követel a haza.

Ám a vészhelyzet nem tartható sokáig. Ha túl sokáig kényszerülnek egy közösség tagjai arra, hogy hétköznapjaikat gúzsba kötve éljék, az ellen elóbb-utóbb fel fognak lázadni. Ha pedig úgy érzik, a kormányzat a vészhelyzetre hivatkozva avatkozik az emberek életébe, azt a hatalommal való visszaélésnek tarthatják, s meg is torolhatják.

A modern parlamentáris demokrácia különösképpen nem kedvez a vészhelyzeti politizálásnak. Ennek legfőbb oka, hogy nem is a vészhelyzet kezelésére találták ki. Épp ellenkezőleg: a nyugati demokrácia alapfeltételezése az, hogy a politika a bevett üzemmenetról szól. A nyugati polgár életét megzavarja a vészhelyzet, $s$ elvárt állampolgári viselkedésében is rendellenességeket tapasztalhatunk. Ezért a politika mindent megtesz azért, hogy a tényleges politikai gondokat az állam - mint az arcana imperii részét - elleplezze a polgárok elól (a fogalomról lásd: Pethő 2007). A második világháború óta nyugateurópai vagy észak-amerikai területen lényegében nem folyt háborús cselekmény.

A pandémia azonban mit sem tud a második világháború után kialakult megegyezésról, a béke- és normalitás-centrikus, ezért apolitikus nyugati politikáról. A vírus megtámadja az ember immunrendszerét, és életére tör. De nem csak az egyénre veszélyes. Amikor a WHO meghirdette a világjárványt, ez annak elismerését jelentette, hogy a vírus közösségeink, mi több, az egész emberiség mint fiktív közösség ellen üzent hadat. Ebben az értelemben meg is képezte az emberiséget mint hadviselő felet, mint egy tábort. A mindenkori ellenség alkotja meg a védősereget, mint közösséget.

Nem véletlen, hogy a politikai vezetôk a harcászatból ismert nyelvhez folyamodtak a jelenség leírására, amikor megosztották a polgárokkal taktikai és stratégiai elképzeléseiket. Ha ugyanis emberek esnek ágynak és halnak meg, a gazdaságot önként le kell zárni, és az emberek életét súlyos korlátozások alá kell vonni, akkor azt nehéz másként leírni, mint háborús állapotként. Tudjuk, ki az ellenség - még ha, sajnos, láthatatlan is -, beazonosíthatóak a veszteségeink, megvannak és folyamatosan frissülnek a fegyvereink is a legyőzésére. Mondhatjuk azt, hogy hidegháború ez, hiszen tüzfegyver nem dördül el. De ha háború, szükségünk van hadvezérre. $S$ a politikának el kell döntenie, vállalja-e a hadvezetéssel járó kockázatot, a bizonytalan dicsőségért, vagy hagyja a háborút a katonákra, $s$ a politikát hermetikusan elzárja a vírussal folytatott csatától. Ha Boris Johnsonra vagy Macron elnökre tekintünk, azt látjuk, igenis felvállalják az ütközést - még ha nem is igazán fúlik hozzá a foguk.

Ám ha Napóleon pozíciójára tör, s maga vezeti ütközetbe seregeit, a demokratikus politikai vezetőnek nehéz lesz visszatérnie a csatatérről a hétköznapi kerékvágásba. Emlékezzünk a háborúból hazatérő római császárokra. Hol a dicsőségben úsztak, hol pedig szembe kellett nézniük a népítélettel - persze általában valamely riválisuk volt az, aki ellenük bőszítette a népet. Ha egyszer átlépted a Rubikont, nehéz megtalálnod a visszafelé vezető utat.

Ezért a parlamentáris demokrácia is megkívánja, és a politikai racionalitás is azt diktálja, hogy amint lehetőség van rá, vissza kell térni a kormányzati gépezet normál üzemmódjához. A hatalompolitikus szocializációja azonban nem ebbe az irányba mutat. Épp ellenkezóleg: amíg csak lehet, a hivatalban lévő vezetó meghosszabbítja azt a jogrendet, amely megkönnyítette számára a cselekvést. ${ }^{3}$

\section{Az állam visszatér}

Az Európai Unió térnyerésével - gondoljunk az európai alkotmányozás egyelőre kudarcot vallott kísérletére -, a globális intézményesülés folyamatával - gondoljunk az emberjogi bíráskodás, a Nemzetközi Valutaalap és a Világbank intézményeire - úgy túnt, a nemzetállamok ideje leáldozóban van. Mivel a globális játéktéren a méret meghatározó, az Európára jellemző léptékú államok veszítettek jelentőségükbőll, hiszen a globális térben nem megfelelő nagyságúak. A globális tér a birodalmaknak

${ }^{3}$ Ez a gondolat természetesen összefüggésbe hozható Machiavellinek a fejedelemmel kapcsolatos nézetével, mely szerint a fejedelem célja, hogy minél tovább megőrizhesse a hatalmat (Machiavelli 2015). Ugyanebbe az irányba mutat Max Webernek a bürokratikus hatalomgyakorlás logikáját elemző gondolatmenete (Weber 1987, 1996). 
kedvez. Az Egyesült Államok, Oroszország, Kína és India is birodalom: olyan hatalmi konglomerátum, amelyet nem a közösség eszménye határoz meg, hanem a kormányzás intézményes felügyelete. Bár a birodalmaknak rossz a sajtója, a nemzetközi kapcsolatok világában ezek vannak igazán otthon.

Nem csoda hát, ha a nagy hagyományú, vezető európai országok - elsősorban Németország és Franciaország, másodsorban Olaszország és Spanyolország - egy idő óta maguk is azt tervezik, hogyan válhatna az egyesített Európa birodalommá. A saját alkotmányos és igazságszolgáltatási hagyományait feladni nem kívánó Egyesült Királyság feltehetóleg azért lépett ki az Unióból, mert az a remény mozgatja, hogy saját birodalmi múltja jogán országuk ma is képes lehet önálló birodalmi tényezővé válni.

A brutális COVID-járvány ebben a „Nyugat alkonya” pillanatban épp az európai birodalomépítés ellenében hatott. A Brüsszel által koordinált védekezés során az lett volna az eredeti politikai cél, hogy ábrázolhatóvá tegye a közös európai fellépés hatékonyságát, erejét. Ehhez képest mind az oltóanyag-beszerzésben, mind az európai oltási igazolvány megszervezésében épp a kitûzött cél ellenkezője igazolódott be. Az európai (tágabban értve a nyugati) nemzetállamok és az Egyesült Államok is versenyhelyzetként olvasták a világjárvány elleni védekezés helyzetét, és éles harc bontakozott ki köztük a védekezés szempontjából kulcsszerepet játszó javak megszerzéséért, a lélegeztető gépektől, maszkoktól és tesztelő eszközöktól az oltóanyagokig.

Mindebben semmi meglepó nincs. A politikai szuverenitás mind a mai napig a nemzetközi jog szerint is természetesen az államot illeti meg. Tudjuk, hogy e szuverenitás bizonyos részét az államközi megegyezés szerint az európai államok az EU-val együtt gyakorolják. Mindez azonban nem teremti meg az EU-t mint demokratikusan felhatalmazott szuverén politikai ágenst.

$\mathrm{Az}$ államok sem egyforma hatékonysággal léptek fel persze. Az egyik kormányzat rátermettebbnek bizonyult, mint a másik. $S$ persze, a védekezés során különböző erősségeket és gyengeségeket érzékelhettünk a különböző kormányzatok esetében a különböző próbatételek során. Ám az világossá vált, hogy az államok kezében vannak azok az eszközök, amelyek ebben a veszélyes helyzetben a védekezést lehetővé tehetik. Az is nyilvánvaló, hogy a nemzetközi közösség sem közösség még. Igaz, számos példáját láttuk annak, hogy bizonyos javakat a kormányok egymásnak adományoztak, ám ezt jól érzékelhető politikai céllal tették. A nemzetközi kapcsolatokat továbbra is az éles verseny és a konfliktusok határozták meg - gondoljunk Kína és Oroszország nyomulására az oltási piacon, vagy a nyugati cégek eltökéltségére az oltási versenyben, miközben milliók váltak a betegség áldozataivá világszerte, mivel hazájuk nem tudta megengedni magának az oltóanyag beszerzését, vagy a gyártó nem tudott számukra terméket biztosítani.

\section{Globális összefüggések}

A globális védekezés lehetséges intézményi formái még nem körvonalazódnak tehát, szemben az állami védekezés jól definiált szintjével. A világjárvány ténye azonban olyan kontextust teremtett, amely egy globális politikai tematikát eredményezett. Gondoljunk a Johns Hopkins egyetem nevezetes, folyamatosan és rohamosan növekvő adatbankjára, mely a globális járványadatokat a teljességre törekedve gyújti és teszi elérhetővé (COVID-19 Dashboard by CSSE). Azzal, hogy így a küzdelem sikeressége számszerúsíthetôvé, és mindenki által ellenőrizhetővé vált, megteremtették a politika globális összehasonlíthatóságának feltételeit.

Mindez azért fontos, mert a politikáról folyó diskurzust nehéz lenne tárgyilagosnak nevezni. A politikai retorika évezredes hagyománya megtanította arra mind a politikusokat, mind az óket bíráló sajtót és nyilvánosságot, hogy nem a tények, hanem az aktuális meggyőzőerő fogja eldönteni, hogy miként viszonyul a széles közvélemény egy-egy adott személyhez, politikai témához, teljesítményhez vagy mulasztáshoz. Ső́t azt is a retorika befolyásolja, hogy mi válhat témává. Ezért nem csodálkozhatunk rajta, hogy a járványtagadás is megjelent - ezzel sokan a tematikát szeretnék meghatározni, míg mások összeesküvéselméletek keretében próbálnak figyelmet kelteni. Mindenesetre a járvány olyan globális témává vált, amely a retorikán túl is összehasonlíthatóvá teszi az országokat. Ráadásul a világjárvány elleni fellépés is - már csak a kifejezésből magából kiindulva is - egyértelmúen globális nyilvánosságot is teremt.

De globális összehangolás helyett soha nem látott globális versengést generáltak a járvánnyal kapcsolatos pánikhelyzetek. Ebben persze nincs semmi meglepő, az lett volna inkább szokatlan, hogy ha a nehéz helyzetre valami globális kibéküléssel válaszolt volna a világ. Ehelyett a nemzetközi kapcsolatok szintjén továbbra is kíméletlen presztízsharc bontakozott ki. Ez olykor akár a piac ideiglenes lebénulásához is vezetett. Ha ugyanis hirtelen hatalmas mennyiségú árura van szükség, a globális piac is meg tud zavarodni, s akkor meglepó reakciókat mutat. Ilyenkor a puszta piaci logikát a globális piaci szereplók politikai érdekei fölülírják. A Nyugatnak Kínában kellett versenyt futnia bizonyos hiánycikkek beszerzése során, $\mathrm{s}$ egyrészt a kínai fél ezt nyilván jócskán ki is használta, másrészt a verseny nem éppen a méltányosság szabályai szerint zajlott. Hallani olyan esetekről, hogy már épp repülőgépre csomagolták a megvásárolt árut, amikor egy másik ország kormánya többszörös árat ígért érte, s végül ennek az országnak a repülőgépére került a küldemény.

Úgy tűnik, ezeken a piacokon a szükség törvényt bontott. A szokásos eljárások helyett a pőre politikai érdekek diktálta nagyhatalmi logika érvényesült. Pedig értékalapon pont arra lett volna szükség, hogy a rideg üzleti logikát is felülírja az emberiesség és a méltányosság elvárásai szerint valamifajta különleges eljárás, amely nem 
feledkezik el a világ nagyobbik felét kitevő szegény és elmaradott régiók járványvédekezéséról sem. Nyilvánvaló, hogy szükség lenne egy globális oltóanyag-gazdálkodási rendre. Ha ugyanis a nagyok nem segítik őket, a pénzügyi nehézségekkel küzdő országok maguk nem tudják belátható időn belül beoltani saját polgáraikat. Ezzel pedig nemcsak regionális járványfészkek alakulhatnak ki, hanem a globális járvány is továbbterjed, s ezzel a gazdagabb államok polgárait is fenyegeti. A globalizáció korszakában ugyanis nincs olyan régió, amely előbbutóbb ne kapcsolódna be a globális hálózatokba.

\section{Miért nem jó az együttmúködés az állam és polgárai között?}

Az együttmúködés hiánya nemcsak az államközi viszonyok területén maradt meg a világjárvány alatt, hanem a belpolitikát is meghatározta. Mindebben semmi meglepő nincs, ha a politika professzionális szereplöire gondolunk. Az államok vezetői hatalmi helyzetben vannak, s - Machiavelli szerint - ennek megörzése mozgatja őket. A politikai pártoktól és érdekcsoportoktól ezért nem várta senki, hogy leteszik a fegyvert, és egyesítik erőiket a koronavírus ellen folytatott harcban.

Elgondolkodtatóbb talán az, hogy a fenyegető hírek hallatára a polgárok sem feltétlenül az összefogás stratégiáját választották. Igaz, láthattunk emlékezetes felvételeket utcai spontán dalolásról, ami persze elsősorban a mediterrán országok hétköznapi kultúráját jellemzi. Ezek a közös éneklések a mindenkit elszigetelő elzártság élményének ellensúlyozását szolgálták, spontán módon alakultak ki és terjedtek, és fontos volt az az üzenetük is, amely az egészségügyi dolgozóknak szólt, s a közösség köszönetét zenésítette meg. Ám az ilyenfajta, a szorongást oldó közösségi élmények meglehetősen ritkán adódtak. Helyettük máshol ott volt a csoportokba verődött fiatalok nehezen értelmezhető utcai randalírozása. Az elzártságot megelégelő, általában perifériára szorult, sokszor bevándorló háttérrel rendelkező fiatalok a vandalizmus, az öncélú utcai erőszakoskodás, a rombolás eszköztárával reagáltak arra a lelki sérülésre, amely a hosszú elzártságból fakadt. Voltak kezdeményezések ennél építőbb közösségi akciókra, együttmúködésre is - például az Egyesült Királyságban önkénteseket toboroztak logisztikai és egyéb, a járvány elleni küzdelemben fontos feladatokra, amelyekre nem volt elegendő munkaerő. Ám a járvány nem igazán tudta összerántani a társadalmakat, és sok esetben új törésvonalakat eredményezett.

De a legfontosabb törésvonal a Leviatán és az egyes állampolgárok között alakult ki. ${ }^{4}$ A hatóságokba vetett bizalom több helyen megrendült. Legalábbis a civil tár-

\footnotetext{
${ }^{4}$ Érdekes ellentétben Hobbes Leviatánjának (1651) nagy hatású üzenetével a kötet borítóján az uralkodó testének tömegét a polgárok teszik ki (Hobbes 1999).
}

sadalom több kérdésben is megtagadta az együttmúködést az állammal. ${ }^{5} \mathrm{Ez}$ a fejlemény benne volt ugyan a lehetőségek között, de több körülmény együttállása kellett ahhoz, hogy csakugyan megtörténjen.

Különösen figyelemreméltó ezek közül a járványtagadás egyre terjedő jelensége. A közösségi médiában olyan álhírek terjednek ellenállás nélkül, amelyek szerint nincs is világjárvány, csak így akar a hatalom az emberek fölé kerekedni. Állítólag az internet szabadon elérhetó platformjai révén ezek az álhírek a hálózatok tagjai között akadálytalanul terjednek. A járványtagadás egyfajta pszeudo-vallásként múködik, mint a laposföld-hívők közössége. Köreikben nem az a lényeges, hogy racionálisan alátámasztható-e az általuk hirdetett dogma, hanem hogy vannak-e olyan karizmatikus közvélemény-formálók, akik elég meggyőzőek ahhoz, hogy manipulálni tudják az emberek gondolkodását ilyen egyértelmúen hamis állításokkal kapcsolatban is. A közösségi média tömeghatása még felderítetlen. De az nem véletlen, hogy Joe Biden amerikai elnök a CNN szerint úgy nyilatkozott, hogy a Facebookon megjelenő vírustagadás ténylegesen embert öl (Judd-Vazquez-O'Sullivan 2021; Az amerikai elnök később visszakozott: Klein-Vazquez-Collins 2021).

A járványtagadás egyfajta anarchista megkérdőjelezése az állami autoritásnak. A járványtagadó megvonja bizalmát az állam intézményeitől, és ha szüksége van rá, saját hitvilágot épít a hivatalos ideológia helyébe. Fontosabb azonban számára a tagadás ethosza, az az erő, amely a tagadásban megnyilvánul. Álláspontja radikalitása érdekében hajlamos a racionális gondolkodás paktumát is felmondani. Többször beigazolódott, hogy amikor a járványtagadó megtapasztalta a járvány súlyosságát, visszavonta nézeteit, de mindez a jelenséget nem tudta visszaszorítani. Épp ellenkezőleg: a világjárvány láthatóvá tette, hogy a nyugati államokban létezik egy belső ellenzék, amely képes követőtábort toborozni teljességgel megalapozatlan állítások mögé is.

Az állammal való együttmúködés megtagadásának egy másik megnyilvánulása a maszkhasználat elutasítása. A maszkellenes érzület lényege: tiltakozunk, mert a kötelező maszkhasználat valami olyasmit kényszerít ránk, ami nem indokolt, és hosszú távú általános kötelezettségként nem fogadható el. Az arc eltakarása lényegében az identitás eltakarása, a maszkkal fedett arc követelménye nem más, mint a társadalom homogenizálására tett tudatos kísérlet. Különösen indokolhatatlannak tûnik a maszkhasználat azok számára, akik egyébként támogatják azt a szintén hatósági előírást, hogy az arc eltakarása nyilvános térben még vallási indokokból kifolyólag se legyen elfogadható. Szerintük a maszk is szemben áll a

${ }^{5}$ Ezzel ellentétes Pierre Manent francia liberál-konzervatív gondolkodó álláspontja, amely szerint az állam tört be megengedhetetlenül mélyen a magánte rületeinkre (Manent 2020b). Az interjú eredetije franciául a Le Figaróban jelent meg (Manent 2020a). 
közbizalom, a személyi felelősségvállalás és a köztér nyilvánosságának elvével.

A maszkhasználatot addig sokan elfogadták, amíg azt valamifajta kölcsönös engedménynek tekintették: a lakosság hajlandó volt elfogadni a maszkot, ha cserébe a hatóság engedett a helyhez kötöttség követelményéból. Ám hosszú távon nagyon is nyomasztónak tûnik ez a fajta életmód, főleg azok számára, akiket foglalkozásuk arra késztet, hogy egész nap hordják a védőeszközt. Ilyen szempontból éles konfliktusok várhatóak az államot általános rendfenntartó erőnek tekintő német államtani hagyomány, és a társadalmat felnőtt és döntésképes emberek csoportjának tekintő angolszász megközelítés között. Másként fogalmazva: a félelemvezérelt, ezért gondoskodó államot elváró, és az egyéni szabadsághoz kockázatok árán is ragaszkodó álláspont között. ${ }^{6}$

A következő szint állam és polgárai vitájában a home office-szal és a helyhez kötöttséggel kapcsolatos. Az elsődleges megállapításunk az lehet, hogy az otthoni munkavégzés előírása tulajdonképpen meglepően sikeres volt. Azok a foglalkozások, amelyek otthonról, távfoglalkoztatásban is üzhetők, minimalizálni tudták veszteségeiket - a munkavégzés folyamatos volt, nem következett be a gazdasági pangás, így a munkahelyek sem kerültek veszélybe. Sőt egyes cégek még takarékoskodni is tudtak azáltal, hogy kiadásaikat csökkentették. Ráadásul számos új szolgáltatás és gazdasági tevékenység tudott rátelepülni az otthoni foglalkoztatásra. Elég talán csak az online vásárlásra gondolni, vagy arra, milyen gyorsan átállt a vendéglátóipar a házhoz szállításra, kiegészítő bevételi lehetőséget teremtve munkát kereső fiatalok tömegeinek.

Ám a kizárólagos otthoni munkavégzést nem lehet sokáig fenntartani. Még akkor sem, ha e mellett racionális gazdasági érvek hozhatók fel. Főleg akkor nem, ha az otthoni munkavégzés kötelezettség, amit ráadásul a lakóhely elhagyásának tilalma is kísér. A röghöz kötést érzékelhetően nehezen viselte a lakosság, ezt is szabadsága korlátozásaként fogta fel - joggal. Az is igaz, hogy a járványügyi szakértők viszont erős érveket hoztak fel mellette. Ebben az esetben is két elvárás - közszabadság és közegészség - ütközőzónájában kell olyan politikai döntéseknek megszületniük, amelyek biztosítják, hogy az áldozatok száma minimalizálható legyen, míg a szabadságmegvonás is a lehető legkisebb mértékú. Mivel egy ilyen kölcsönösen elfogadott nyerő helyzetnek kicsi az esélye, ezért a döntés lényege: milyen áldozatot hozzon a politikai közösség: a szabadságért mondjon le a leghatékonyabb járványkezelésről, vagy a járványkezelés érdekében szabadsága egy részéról. A jó döntésnek vannak elvi alapjai, de valójában a tényleges helyzetre válaszol,

\footnotetext{
${ }^{6}$ A kormányzással kapcsolatos angolos, konzervatív felfogás Oakeshott-féle leírá sát lásd Hörcher 2019: 177-189. A németes és az angolos orientáció összehasonlítására Hörcher 2002: 369-380.
}

ezért nem ültethető át, mint jó gyakorlat, más gazdaságipolitikai-kulturális feltételrendszerbe. ${ }^{7}$

Az otthoni munkavégzésnek például van egy előre nem látható következménye. Azok, akik nem megfelelő körülmények között élnek, még inkább érezhetik kiszolgáltatottságukat, hátrányos helyzetüket. Azok viszont, akik átlagos, vagy annál jobb körülmények közt laknak, újra felfedezhették otthonuk szépségét, otthonosságát. Hogy védelmet nyújt a mindennapokban. Talán nem véletlen, hogy a lezárás idején a lakásfelújítások egész hulláma indult el: az otthon töltött idő növekedésével egyre többen érezték úgy, hogy otthonuk szebbítésre vár, és hogy erre kiválóan alkalmas a home office időszaka. Bár rövid távon ez elég súlyos piaci zavarokhoz vezetett - a túlzott keresletnek köszönhetöen hamar eltúntek a jó szakemberek és a leggyakoribb építőanyagok -, annyi haszna biztosan volt, hogy az emberek befektették megtakarításaikat, munkalehetőséget adtak másoknak, s a közvagyon állapotát is javították. Ám a túlfütött építőipar helyzete és a nagy építési bumm annyiban mégis vészjósló, hogy valamifajta építési buborék keletkezhetett, amely azzal fenyeget, hogy elóbb-utóbb kipukkad, s nem tudjuk, akkor pontosan mi is fog történni.

Végül az utolsó nagy megosztó téma, ami szembeállítja a polgárt és az államot a világjárvány kapcsán, maga az oltás/oltakozás. ${ }^{8}$ Egyfelől ott van az állam elvárása, hogy polgárai minél nagyobb számban oltassák be magukat, hogy kialakuljon a közösség védekező ereje. Ám ezt a felszólítást az állam láthatólag nem tudja hatásosan kommunikálni. A legtöbb államban körülbelül a lakosság 50 százaléka felett rendkívüli módon lelassul az oltakozás üteme. Sok helyütt pedig hónapok alatt sem jutottak el idáig. Másfelől viszont jelen van egy fordított elvárás / csalódás összefüggés is oltás ügyben. Egyes országokban az állam nem tud eleget tenni a lakosság (egy része) jogos oltási igényének, akár anyagi, szervezési vagy technológiai hiányosságok miatt.

Mindkét elégedetlenségtípus esetében súlyos feszültség keletkezhet állam és polgárai között. S be kell vallani, egyik akadály sem könnyen orvosolható, vagyis a konfliktusok kialakulása borítékolható. Egyrészt a lakosság majd felét kitevő népességcsoport nehezen érhető el az állami kommunikáció eszközeivel - ami a képviseleti demokrácia teljesítőképességének a határait is jól láthatóvá teszi. Náluk valószínúleg csak a háztól házig haladó személyes kampány számíthat sikerre - ebben pedig a helyi politikának, a lokális vezetésnek lenne szerepe, ugyanis a járvánnyal való megbirkózásnak nemcsak globális és állami,

${ }^{7}$ E tekintetben érdemes felidéznünk, hogy már Politika címú múvében Arisztotelész is amellett érvel, hogy minden polisz más politikai helyzetben van, s ezért nehéz a politikában általánosan érvényes elveket vagy törvényeket találni. A politika ebben az értelemben nála is a meglévő helyzetre adott helyes válasz. Arisztotelész politikai filozófiájának általános bemutatására lásd: Miller 2017.

${ }^{8}$ E szópár kapcsán érdemes elgondolkodnunk a járvány nyelvi hatásain is: sok új szó vagy fordulat keletkezett, vagy ismeretlen kifejezés vált divatossá. A járvány sikeres kezelése bizonyos értelemben a nyelv fölött gyakorolt hatalom kérdése is, ahogy a kulturális háború esetében is láttuk. 
hanem helyi csataterei is vannak. Az önkormányzatoknak kell olyan helyismerettel rendelkezniük, hogy választ adhassanak az olyan kérdésekre, hogy milyen a lakosság hangulata, beállítódása, s hogy ennek megfelelően kihez milyen módon, milyen retorikával és milyen érvekkel lehet eljutni. Ami arra hívja fel a figyelmünket, hogy a helyi politika jelentőségét, elméletét sokkal kevésbé dolgozta ki a politikaelmélet és -filozófia, mint az állami és az államfölötti politizálás intézményes mechanizmusainak elvi alapjait (lásd erről Hörcher 2021: 298).

Az oltakozási kedv, illetve az oltóanyag elérhetősége körül kialakuló vita elfedni látszik az egyébként elért eredményeket. Az oltóanyag gyors felfedezése és ipari méretú termelésének megszervezése kiváló eredmény - még ha magának a világjárványnak a kialakulásában valószínúleg a politikai döntéshozók hibái is szerepet játszhattak. Érthető okokból, a hibákról folyó vita aktuálpolitikai felhangokkal terhes, úgy belpolitikailag, mint a globális politikai színtéren. Meglehetősen kétes szerepet játszott például a WHO a világjárvány korai szakaszában, s mindmáig adós a járvány kialakulásának feltárásával. Ám ugyanez a szervezet joggal figyelmeztet folyamatosan a védekezés területi egyenlőtlenségeire, s arra, hogyha a gazdagabb országok nem juttatnak oltóanyagot a szegényebb régiókba, annak rájuk nézve is veszélyes következményei lehetnek. India ilyen szempontból az állatorvosi ló példája volt. De továbbra is számos szürke zóna található világszerte, ahonnét nincsenek megbízható információink, ugyanakkor az kizárható, hogy oda ne érjen el a vírus. Ezért ezeket a területeket továbbra is súlyos kockázati tényezőnek kell tekintenünk.

\section{Társadalmi kihívások}

A dolgozat befejező részében a járvány társadalmi, kommunikációs és gazdasági hatásai közül emelünk ki néhány fontosabbnak tưnő összefüggést. A társadalmi szempontok közül az egyik legszembeötlőbb a generációk között a járvány által kirobbantott konfliktus. Az eltérô életmód és egészségi állapot miatt a fiatalok nyilvánvalóan másként reagálnak a járvány fent említett és további következményeire is, mint az idősek. Már a járvány kirobbanásakor megfigyelhető volt a bünbakképzés folyamata. A fiatalok azzal vádolták a nyugdíjasokat, hogy nem hajlandók változtatni szokásaikon, s ezzel a vírus terjedését segítik - például amikor nem vették tudomásul a karantént, vagy amikor vásárlásaikat nem alakították a helyzethez. De a helyzet fordítottja is előfordult: ekkor a fiatalokat nevezték felelőtlennek az idősebb korosztályok, amiért azok továbbra is tömegekben verődtek öszsze, s ezzel könnyítették a vírus terjedését.

A generációk közötti konfliktusok eleve is kódolva vannak egy táradalomban, hisz az eltérő nemzedéki élmények másfajta életformákat alakítanak ki, s eltérő értékrendeket is eredményeznek. Különösen igaz ez egy technológiai ugrásokat hozó időszakban, mint amilyen- ben most él az emberiség. Ráadásul az emberi életkor radikális meghosszabbításával ezek a konfliktusok csak még valószínúbbekké válnak. Hisz az idős emberek nyilván nem tudnak lépést tartani a technológiai fejlődéssel, nem tudnak alkalmazkodni az új elvárásokhoz sem. A fiatalok pedig egyre inkább hajlamosak a „boomer”-ek lekezelésére, akiket ráadásul minden rossz okozójának is tartanak. Ezt a generációs csapdát teszi még elkerülhetetlenebbé a járvány, amikor az egyes nemzedékek érdekeit egymás ellen fordítja. Mindezt tovább nehezíti a gazdasági visszaesésnek a generációsan nem egységes hatásmechanizmusa - erről lásd később.

Ugyancsak súlyos társadalmi problémát jelenthet az, hogy a járvány és kezelése lelki betegségeket is előidéz. A bezártság, az izoláció nem tesz jót az emberi léleknek. Az ember, ahogy legalább Arisztotelész óta tudjuk, társas lény, egyedül nem érzi jól magát. A hosszú elzártsági szakaszok lelassítják az emberek társas kapcsolatrendszerét, de legalábbis átrendezik azt, sokan elszoknak a társas viselkedés hétköznapi rutinjaitól. Különösen érzékenyen érintheti ez a fiatalabb generációkat, amelyek tagjai még járatlanok a társas kapcsolatépítésben. A járvány alatt született csecsemók például az idegenektől megijednek, nem tudnak megfelelően reagálni az új arcok megjelenésére. A nagyobbacska gyerekek számára azért veszélyes ez az elzárt időszak, mert pont ebben az életszakaszban kellene megtanulniuk társas készségeik jó részét. A kamaszok és a fiatalok esetében pedig a közösségi élmények hiánya vezethet torzult személyiségfejlődéshez, de legalábbis depressziós hajlamhoz, párkapcsolati problémákhoz, vagy a párválasztás szokásos módjaiban való járatlansághoz, a barátság élményének hiányához. Mindezek a jelenségek a fiatalabb nemzedékek társadalmi beilleszkedési zavarait eredményezhetik, adott esetben a társadalomellenes viselkedési formák szaporodását is magukkal hozhatják.

\section{Kommunikációs kihívások}

A társadalmi feszültségek leggyakoribb forrásai közé tartoznak a kommunikáció zavarai. Az, hogy az ember társas lény, az egyik legfontosabb készségévé avatja a kommunikációt, a többiekkel folytatott információcserét, vagy egyszerúen csak a tapasztalatok megosztásának, közös és kölcsönös kinyilvánításának gesztusát. Közösség nélkül nincs nyelv (lásd Wittgenstein privátnyelv érvét), s nyelv nélkül nincs közösség. Ahhoz, hogy a világot értelmezni kezdjem, szükségem van valakire, akivel a gondolataimat meg tudom osztani. Ha erre - objektív vagy szubjektív okokból - nem vagyok képes, biztos, hogy világértelmezésemben zavarok támadnak.

Ugyanez igaz a közösség egészére. Ha a társadalom tagjai nem értik egymás szavát, nem tudnak egymással értelmesen kommunikálni, akkor az összeütközés elkerülhetetlen. Továbbá igaz az állam és polgárai viszonyára is: a második világháború óta tudjuk, a hatalom a médiát politikai kommunikációra is tudja használni. Ám lehet, 
hogy pont az információs zuhatag az, ami megakadályozza hatalom és polgár értelmes kommunikációját. Mindenesetre a jelek szerint van egy olyan réteg, amelyik - leginkább a bizalom hiánya okán - lényegében süket a politikai kommunikáció megnyilvánulásaira. Ennek nyilvánvalóan súlyos következményei vannak világjárvány idején. Ám hosszabb távon is elgondolkodtató a felvetés: a nyugati polgári demokrácia dialogikus hatékonysága véges. Hiszen ha igaz, hogy a politikai kultúrától függően a népességnek akár a fele nem hajlandó együttmúködni a hatalommal, akkor bizony az a feltételezés, hogy ezek csakugyan az egyenlőség elvén alapuló rendszerek, illúziónak, esetleg üres ideológiai szólamnak, netán hamis propagandának túnhet.

Ha az állam nem jut el minden üzenetével a polgárok teljes közösségéig, a kereskedelmi médiának is nagy erőfeszítést kell tennie ugyanezen cél elérése érdekében. Ha az online hírportálok címadási gyakorlatára tekintünk, rögtön látni fogjuk, hogy milyen eszközöket vet be a hírés szórakoztatóipar a néző/olvasó/hallgató/fogyasztó megszólítása érdekében. Az érzelem kiváltásának minden hagyományos eszközét bevetik - s ez alól nem kivétel a járvánnyal való félelemkeltés sem, a pánikreakció kiváltása érdekében. Mintha a populista görög demagógok és római néptribunok retorikai iskolájában nevelkedtek volna.

Mindez nem lenne érdekes, ha a hatása nem lenne olyan riasztó. A baj az, hogy a félelemkeltést és érzelmi sokkolást iparszerüen űző portálokon nevelkedett ifjak, csakúgy, mint az ebbe belecsöppent felnőttek, nem feltétlenül tudják megúszni e hatásmechanizmust pszichés zavarok nélkül. Ha a Greta Thunberg jelenségre tekintünk, láthatjuk, hogy egy egész generációt tudott rabul ejteni a klímaválságtól való rettegésével. Egyelőre még nincs tudomásom róla, hogy a koronavírusnak hasonló arca született volna, mint amilyen Greta - de meggyőződésem, hogy a profi lélekhalászok egy ilyen médium nélkül is sikeresen instrumentalizálták a járványt saját profitcentrikus céljaik érdekében.

De természetesen a politikai hackerek is megpróbálták saját uralmuk alá vonni a témát. A kultúrháború és identitáspolitika idején ugyanazokat az eszközöket vetik be a politikai kommunikációban, mint a kereskedelmi reklámokban. A lényeg: megfogni a másik figyelmét, akármilyen eszközzel is történjen ez. Márpedig az ember, ahogy Hume olyan emlékezetesen megmutatta, szenvedélyei foglya (Hume 2006; a témáról részletesebben: Horkay Hörcher 2012: 43-60). Nehezen tudja kontrollálni érzéseit, fóleg a rapszodikusabb természetűeket: haragját, irigységét, földi vágyait. $S$ a kortárs politika (ahogy a reklámipar, vagy korábban a retorika múvészete) e szenvedélyek vámszedője: képes a saját érdekei szolgálatába becsatornázni tagolatlan érzelmi elköteleződéseinket.

Szembeötlő a közösségi média közvéleményformáló szerepe még egy világjárvány idején is. $S$ nem csak arra gondolhatunk, hogy miként lázadtak fel a legnagyobb médiaszolgáltatók az Amerikai Egyesült Államok elnöke ellen. Persze ez is tanulságos. Hogy miként használták fel a vírus által kiváltott aggodalmat e szolgáltatók politikai céljuk, jelesül az elnök megbuktatása, de legalábbis újraválasztásának meghiúsítása érdekében. Kétségtelen, hogy Trump elnök súlyos hibákat követett el a járványkezelésben (Baccini-Brodeur-Weymouth 2020). Eleinte, csakúgy, mint a klímaválságot, megpróbálta lekicsinyelni a dolgot. Majd a kontrollt szerette volna átvenni fölötte. Aztán belátta, hogy ez nem az ő témája, s ráhagyta a szakemberekre. Kritikusai, így a fóáramú média és az értelmiségi véleményformálók viszont kihasználták a választókban dolgozó aggodalmat, s a Trump ellen mindenre kész internetes aktivisták a közösségi médiumokban nyomultak - ahonnét aztán végül egyszerúen kiutasították az elnököt a szolgáltatók. A közösségi médiaszolgáltatók együtt mozdultak annak hétköznapi harcosaival, olyan klímát teremtve, amelyben már Trump támogatása is a cancel culture agresszív reakcióit váltotta ki. Arról nem beszélve, hogy kitiltása révén Trumpot legfontosabb politikai fegyverétől fosztották meg. Pedig az elnök (és stábja) kifejezetten erős volt ezen a kommunikációs csatornán. A világ legnagyobb hatalmú vezetőjének brutális kitiltásával pedig a médiaszolgáltatók a demokrácia önjelölt kapuőreinek pozíciójába tornázták magukat, átvéve ezt a szerepet a mainstream médiától. De vajon mi adta demokratikus felhatalmazásukat egy ilyen lépés megtételére? Pontosabban: mi más, mint monopol helyzetük a piacon?

\section{Gazdasági kihívások}

És ha már monopolhelyzetnél tartunk, és a piacnál: hogyan reagáltak a gazdaság szereplői általában a járványra? Melyek a legfontosabb gazdasági kihívások a világ, illetve az egyes államok vezetői előtt ebben a helyzetben?

Talán a legfontosabb szereplők ebben a játszmában a gyógyszergyártók voltak. A világon soha nem látott versenyfutás indult el ugyanis az oltóanyag és a betegség kezelésére alkalmas gyógyszerek kifejlesztésére. Ezek közül is elsőbbsége volt az oltóanyagnak, ami arra utal, volt egy olyan szakmai konszenzus, amely szerint a megelőzés fontosabb, mint a már bekövetkezett betegség kezelése. Ebben lehet is valami, ha a puszta számokat nézzük, s mi mást nézhetne a politikai elemző egy világjárvány áldozatainak összehasonlításakor. Nyilvánvaló, hogy többeket lehet megmenteni (és olcsóbban is) oltással, mint a gyógyszeres kezeléssel. Ám a gyógyszergyártók viselkedése több mint elgondolkodtató volt. És nem csak a versenyelőny méltánytalan megszerzési módjaira gondolhatunk - ez a verseny eleve nem lehetett fair, hiszen mind a know-how, mind az anyagi források, mind a humán erôforrás tekintetében túlságosan is súlyosak az aránytalanságok a gyógyszeripari szereplők között is. Elvileg létezett egy tudástranszfer a kutatásban részt vevók között, s a szakirodalom is megpróbálta az információk megosztását támogatni. Mégis, a vezető nyugati hatalmak között is éles vakcinadiplomácia zajlott. Ahogy a 
világpolitikai színtéren is: a kínai és az orosz oltóanyag európai hasznosítása ellen mindent megtett az Európai Gyógyszerügynökség is. Az is nyilvánvaló ugyanakkor, hogy a kínai és az orosz fél is nagyhatalmi játszmákat játszott, amikor amellett lobbizott, hogy vakcináját feltegye a világ járványtérképére - $s$ valljuk be, e téren nem is bizonyultak teljesen sikertelennek. Ám a gyógyszergyártók lobbizását bátran nevezhetjük méltatlannak egy ilyen veszedelmes ellenséggel vívott harcban. Az államok ugyanis teljes mellszélességgel támogatták saját gyártóikat, s kritizálták az ellenfelek készítményeit. Ennek talán legnyilvánvalóbb példája Franciaország, amelynek nem sikerült előrukkolnia egy engedélyeztethető termékkel, de mindent megtett bizonyos termékek honi terjesztése ellen.

Ezek jól ismert diplomáciai húzások, amelyeknek érvényességét a geopolitikai realitások adják. Ezekhez képest léptékében egész más a jelentősége annak a kérdésnek, hogy vajon miért is tarthatták meg a nagy gyógyszergyártók a védőoltásaik fölötti rendelkezési jogot. Hiszen ha világjárvány miatti globális vészhelyzet van - vagyis az emberiség egészét veszélyeztető helyzet, az talán elegendő ok arra, hogy a készítményeket az egész emberiség számára elérhetővé tegyék.

Persze vannak olyanok, akik azt állítják, a tiszta piaci logika jól megoldja az elosztás igencsak összetett kérdését. Annyiban talán igazuk is van, hogy nem feltételezhető, hogy helyes lenne, ha egy globális világjárványügyi központ, mondjuk a WHO gyakorolhatna jogot az elosztás felett. Ám megfontolandó, hogy nyilvánosságra kellett volna-e hozni és mindenki számára elérhetővé tenni e készítmények gyártási módját - ha mást nem úgy, hogy a gyártókat kártalanítják érte. Létre lehetett volna hozni egy olyan adatbankot, amely az összes elfogadott vakcina eljárását feldolgozza, és minden gyógyszergyártó számára elérhetővé teszi. Ha ez nem megvalósítható globálisan, legalább európai szinten lehetett volna rá kísérletet tenni. Úgy tünik, az Európát - lényegében közvetlen demokratikus felhatalmazás nélkül - irányító nagy országok erre nem éreztek hajlandóságot, pedig az egyenlőtlenségek hosszú távon összeütközést generálnak, együttmúködés helyett. Márpedig a globális nyájimmunitás kialakulásáig valószínúleg nem lehet megfékezni a járványt sem.

De a járvány gazdasági összefüggéseinek van egy ennél is tágabb nézőpontja. A társadalmi távolságtartás biztosítására elrendelt helyhez kötöttség eredményeképp a világ jó részén lényegében leállt vagy nagyon lelassult a gazdaság - mégpedig több ütemben, ahogy a járványhullámok egymást követték. Ennek eredményeképp pedig súlyos veszteségek keletkeztek a világgazdaságban éppúgy, mint - az elóbbiból is kifolyólag - a munkavállalók körében. A gazdaság egyes szférái nagyon is eltérően, mondhatni hektikusan reagáltak a helyzetre - ezért a nemzeti (és nemzetközi) gazdasági-pénzügyi egyensúly bizony igencsak labilis és kiszámíthatatlan lett. Bár sokak szerint remény van egy felpattanó görbére a gazdasági aktivitás tekintetében, mások hosszú távú válsághatásokra számítanak a nyugati világban éppúgy, mint világgazdaságilag. A politikaelmélet számára ebból az a tény különösen érdekes, hogy az efféle gazdasági válságra nincs egységes recept, hiszen mindig az adott körülmények határozzák meg az optimális megoldást. Mégis, összehasonlíthatatlan helyzetük ellenére is, a belpolitikai és a külpolitikai szereplők is hajlamosak a válságkezelés öszszehasonlítására: a nemzeti megoldások közötti versenyeztetésre. Ahogy a sportban, a kultúrában és a politikában, a gazdaságban továbbra is a nemzeti szint a domináns, s a nemzetgazdaságok közötti viszonyra a verseny a jellemző (Fonta 2020).

\section{Konklúzió}

A járvány, már most látszik, egyfajta vízválasztóként, vagy nulla pontként szolgál, ahogy az volt a vasfüggöny lebontása, szeptember 11-e, vagy a 2008-as gazdasági válság. De lehet, hogy hatása még nagyobb lesz - ha így alakul, 1945 szerepét töltheti be. Újraosztja a lapokat, s a politikai éleslátással rendelkező közösségek, vagy akiknek szerencséje van, akár profitálhatnak is ebből a katasztrófából. Másfelől lesznek olyan kormányzatok is, amelyek a lakosság egészsége érdekében hozott áldozatok miatt úgymond elvétik a helyes arányt a védekezés és a gazdaság életben tartása finom egyensúlyában, és nem bizonyulnak majd sikeresnek a kialakult éles versenyben. Ahogy minden más helyzetben, most is lesznek olyanok, akik helyes döntéseik eredményeképp kedvezőbb helyzetbe kerülnek. Mások viszont saját hibájukból, vagy az események előre nem látható összjátékának eredményeképp elbuknak. Ahogy máskor sem, most sem remélhetünk igazságos kimenetet, a politikai verseny az emberi természetnek megfelelően, sokszor méltánytalan eredményeket hoz.

Tágabb összefüggésben az a kérdés, hogy vajon képes lesz-e a globális közösség levonni a tanulságokat a világjárvány jelenségegyütteséből, vagy a kialakult helyzet még nem éri el ezt az ingerküszöböt, ami cselekvésre serkent ebbe az irányba, illetve a széttartó érdekek összeegyeztetése könnyen kudarcot vall. Mindkét utóbbi esetben feladata lesz a politikai filozófiának a helyzet elemzése, és a következtetések levonása.

\section{Irodalomjegyzék}

Arisztotelész. Politika. ford. Szabó Miklós, az eredetivel egybevetette Horváth Henrik. https://mek.oszk.hu/04900/04966/04966. htm [letöltve: 2021. július]

Baccini, L., Brodeur, A. \& Weymouth, S. (2020) The COVID-19 Pandemic and the 2020 U.S. Presidential Election, IZA DP No. 13862. http://ftp.iza.org/dp13862.pdf [letöltve: 2021. július]

Balázs Z. (2005) Emberi méltóság. Jogelméleti Szemle, No. 4. http:// jesz.ajk.elte.hu/balazs24.html [letöltve: 2021. július] 
Ball, T. \& Bellamy, R. (eds) (2003) The Cambridge History of 20th Century Political Thought. Cambridge, Cambridge University Press

COVID-19 Dashboard by the Center for Systems Science and Engineering (CSSE) at Johns Hopkins University (JHU). https://coronavirus.jhu.edu/map.html [letöltve: 2021. július]

Freeden, M. (1996) Ideologies and Political Theory: A Conceptual Approach. Oxford, Oxford University Press

Hegel, G. W. F. (1971) A jogfilozófia alapvonalai. Budapest, Akadémiai Kiadó

Hobbes, T. (1999) Leviatán, vagy az egyházi és világi állam anyaga, formája és hatalma. Ford. Vámosi Pál, Budapest, Kossuth Kiadó

Horkay Hörcher, F. (2012) Hume és az ízlésesztétika brit paradigmája. Magyar Filozófiai Szemle, Vol. 56. No. 1. http://real.mtak. hu/34212/1/Horkay_Horcher_Ferenc_Hume_es_az_izlesesztetika_brit_paradigmaja_u.pdf [letöltve: 2021. július]

Hörcher, F. (2002) The question of the limitation of the state by the law: a comparison of Kelsen's and Hayek's approach. Rehtstheorie, No. 2-4.

Hörcher, F. (2019) Government as a British Conservative Understands It: Comments on Oakeshott's Views on Government. In Kos, E. S. (szerk.) Michael Oakeshott on Authority, Governance, and the State. London, Palgrave Macmillan

Hörcher, F. (2021) The Political Philosophy of the European City. From Polis through City-State, to Megalopolis? Lexington Books, Lanham (MD), Amerikai Egyesült Államok: Rowman and Littlefield

Hume, D. (I. 1992, II. 1994) Arról, hogy lehetséges-e a politikai tudomány. In: David Hume összes esszéi. Budapest, Atlantisz

Hume, D. (2006) Értekezés az emberi természetról. Ford. Bence György. Budapest, Akadémiai Kiadó

Judd, D., Vazquez, M. \& O'Sullivan, D. (2021) Biden says platforms like Facebook are 'killing people' with Covid misinformation. CNN, Updated 2158 GMT (0558 HKT) July 17, 2021. https:// edition.cnn.com/2021/07/16/politics/biden-facebookcovid-19/index.html [letöltve: 2021. július]

Klein, B., Vazquez, M. \& Collins, K. (2021) Biden backs away from his claim that Facebook is 'killing people' by allowing Covid misinformation. CNN, Updated 0031 GMT (0831 HKT) July 20, 2021. https://edition.cnn.com/2021/07/19/politics/joebiden-facebook/index.html [letöltve: 2021. július]

La Fonta, T. (2020) The COVID-19 crisis and the come-back of the nation-state in Europe, RPP Group. https://rpp-group.com/rppblog/news-articles/the-covid-19-crisis-and-the-come-back-ofthe-nation-state-in-europe/ [letöltve: 2021. július]

Machiavelli, N. (2015) A fejedelem. Ford., jegyz. Lutter Éva. Budapest, Helikon Kiadó

Manent, P. (2020a) «Il y a longtemps que nous sommes sortis à bas bruit du régime démocratique et libéral»

https://www.lefigaro.fr/vox/societe/pierre-manent-il-y-a-longtemps-que-nous-sommes-sortis-a-bas-bruit-du-regime-democratique-et-liberal-20200423 [letöltve: 2021. július]

Manent, P. (2020b) Time to Wake Up! First Things. https://www. firstthings.com/web-exclusives/2020/04/time-to-wake-up [letöltve: 2021. július]

Miller, F. (2017) Aristotle's Political Theory. The Stanford Encyclopedia of Philosophy (Winter 2017 Edition), Edward N. Zalta (ed.) https://plato.stanford.edu/archives/win2017/entries/aristotlepolitics/ [letöltve: 2021. július]

Pethő, S. (2007) Arcana Imperii. A sacrum és a politicum kapcsolatának történetéhez. Budapest, Károli Gáspár Református Egyetem Hittudományi Kara

Skinner, Q. (2009) A Genealogy of the Modern State. British Academy Lecture, Proceedings of the British Academy, Vol. 162, 2008 Lectures

Weber, M. (1987, 1996) Gazdaság és társadalom 1., 2/3. Budapest, $\mathrm{KJK}$

A cikk a Creative Commons Attribution 4.0 International License (https://creativecommons.org/licenses/by/4.0/) feltételei szerint publikált Open Access közlemény, melynek szellemében a cikk bármilyen médiumban szabadon felhasználható, megosztható és újraközölhető, feltéve, hogy az eredeti szerző és a közlés helye, illetve a CC License linkje és az esetlegesen végrehajtott módositások feltüntetésre kerülnek. (SID_1) 